\title{
KEY RESPONSIBILITIES IN THE PROCESS OF PUPILS' INDEPENDENT WORK IN THE SUBJECT OF TECHNOLOGY
}

Jaroslav ŠOLTÉS, Prešovská Univerzita, FHPV v Prešove, Slovenská republika

Přijato: 21. 8. 2016 / Akceptováno: 17. 10. 2016

Typ článku: Výzkumný článek

DOI: $10.5507 /$ jtie.2016.031

Abstract: The aim of the presented study is to present one of the essential competences of pupil, and that is the creation of selected key competencies. Selected competencies in the subject Technology comprises of capabilities of pupil that enable them to clarify the natural laws, use and operate modern technical resources, and to master technical knowledge. The basis for successful teaching is to create conditions for the development of competencies and possible application of different kinds of independent and creative activities in the classroom. In the realization of research in our workplace, we have investigated those competencies, which carry distinctive features of activities that achieve very good performances of pupils in the technical field.

Key words: pupil, key competencies, research on selected key competencies, interactive teaching

\section{KLÚČOVÉ KOMPETENCIE V PROCESE SAMOSTATNEJ PRÁCE ŽIAKOV V PREDMETE TECHNIKA}

Abstrakt: Cielom predkladanej štúdie je približit' jednu z podstatných profesionálnych spôsobilosti učitela, ako je vytváranie vybraných klúčcových kompetencií užiakov. Vybrané kompetencie $v$ technike predstavujú spôsobilosti žiaka, ktoré mu umožňujú objasnit' prírodné zákonitosti, použivanie a ovládanie moderných technických prostriedkov, zvládnut’ technické poznatky. Základom úspešného vyučovania je vytváranie podmienok pre rozvoj kompetencii a možné uplatnenie rôznych druhov samostatných a tvorivých činností vo vyučovaní. Do vyučovacieho procesu „vstupuje“ a ovplyvňuje celý rad činitelov. V rámci realizácie výskumu na našom pracovisku, sme zistovali tie kompetencie, ktoré nesú charakteristické prvky činnosti, pri dosahovaní vel'mi dobrých výkonov žiakov $v$ technickej oblasti.

Klúčové slová: žiak, klúčové kompetencie, interaktívne vyučovanie.

*Autor pro korespondenci: jaroslav.soltes@unipo.sk 


\section{1 Úvod}

Určenie nového obsahu prírodovedných a technických predmetov na základnej škole je úzko späté jednak s výchovno - vzdelávacími ciel'mi, materiálnymi podmienkami školy, závisí od záujmov a vyspelosti žiakov a v neposlednom rade aj od ich snahy k prvotnej profesionálnej orientácii. Škola si v súčasnosti kladie za ciel' všestranný rozvoj l’udskej osobnosti, preto je povinná prispievat' k rozvoju tvorivých dispozícií, technických zručností a schopnosti žiaka. Učitelia neustále skúšajú nové prístupy, spôsoby, experimenty. Jednou z podstatných profesionálnych spôsobilostí učitel'a je jeho vzt'ah k žiakom a vytváranie vybraných kompetencií v rámci edukačného procesu. Tvorivo zameraný učitel' pri optimálnom vzt’ahu k žiakom, posilňuje interakcie so žiakmi. Podporuje dôveru každého žiaka vo svoje schopnosti, akceptuje každého žiaka. Určujúcim smerom v práci so žiakmi je uplatňovanie všetkých prvkov v rámci obsahu vyučovania, ktoré napomáhajú formovat' u žiakov súhrn prírodovedných, technických, konštruktérskych a technologických vedomostí a zručností. Jednou z možností, ako zapojit' žiaka do tejto činnosti, je využitie a posúdenie miery uplatnenia samostatnej práce, ako edukačného prostriedku vo vyučovaní, s možnostou použitia rôznych technických prostriedkov a informačnej techniky. Pri posudzovaní miery jej uplatnenia na rozvoj aktivity žiaka, práca žiakov v edukačnom procese, sa prejaví aktívnou činnost'ou, na základe uvedomelého úsilia, ktorého ciel'om je osvojit' si príslušné kompetencie, postoje alebo spôsoby správania. Práve týmto kompetenciám a možnostiam ich rozvíjania prostredníctvom školského kurikula je venovaná táto štúdia. Môže byt’ podnetom a inšpiráciou pre metodikov a samotných učitel'ov na základných školách.

\section{Použité výskumné metódy}

Pri rozpracovaní predkladanej štúdie sme vychádzali z analýz pomerne úzkej škály dostupných domácich zdrojov, vybraných zahraničných zdrojov a materiálov rozpracovaných v rámci školskej koncepcie EU. Pri vymedzení pojmov kompetencie, predkladaného návrhu vybraných klúčových kompetencií, vytváraní kompetencií, sme využili naše skúsenosti z pedagogického výskumu, z našich projektov, ale aj z našich prác, ako aj z prác viacerých zahraničných autorov. Z hl'adiska klasifikácie druhov pedagogického výskumu sa riešitelia projektu rozhodli a v školskej praxi realizovali aplikovaný experimentálny výskum krátkodobý, skupinový, heuristický výskum. Na základe analýzy metód vedeckého výskumu (Gavora, a kol. 2010) a vykonaní analýzy reálnych možností získat' objektívne výsledky výskumov na overenie stanovenej hypotézy a tiež hodnotenia možností výskumného tímu a ZŠ, tím sa pre experimentálne účely rozhodol použit', ako hlavnú metódu výskumných aktivít, metódu pozorovania. Pomocnou metódou bola metóda rozhovoru, krátke rozhovory s vyučujúcimi a žiakmi s ciel’om zistit' vybrané názory na vypracované učebné materiály, technické prostriedky a použité modely výučby.

\section{Vymedzenie základných pojmov}

Problematike kompetencií sa začala venovat' pozornost' už začiatkom 80 - tych rokov 20. storočia. V roku 1973 vyšiel článok amerického psychológa Davida C. McClellanda "Testing for Competence rather than Inteligence“ (Prednostné skúmanie kompetencií pred skúmaním inteligencie). Autor vo svojom článku zdôrazňuje potrebu zohl'adňovat' pri výbere pracovníkov ich kompetencie a nie inteligenciu. Poukázal na to, že tradičné hodnotenie podl'a 
školského prospechu, alebo stupňa akademického vzdelania nám neposkytuje odpoved' na to, ako sa v budúcnosti bude človeku darit'. Navrhuje skúmat' úroveň špecifických osobnostných rysov akými sú: schopnost' vcítenia sa, sebakontroly, vlastnej iniciatívy a iné. Pojem klúčové kompetencie popísal prvýkrát už Mertens (1974), ale v našich vzdelávacích programoch (pozri Milénium - Národný program výchovy a vzdelávania v Slovenskej republike na najbližších 15 až 20 rokov), až koncom roku 2001 sa po prvýkrát objavujú klúčcové kompetencie, ako požiadavky na výsledky vzdelávania žiakov, ktoré nevychádzajú zo špecifík jednotlivých predmetov, ale dotýkajú sa univerzálnejších znalostí, schopností, zručností a postojov, ktoré bežne potrebujeme vo svojom živote a ktoré sú využitel'né v mnohých životných i pracovných situáciách. Tieto sú označené ako klúčové kompetencie. Hlavným motivačným dôvodom pre ich štúdium bola snaha pri hl'adaní ciest k novej, efektívnejšej, pre žiakov prítažlivejšej a pre ich osobné a profesionálne uplatnenie užitočnejšej školy. Terminológia slúžiaca k označeniu fenoménu tzv. klúčových kompetencií sa začala formovat' v anglicky hovoriacich krajinách a prešla vývojom od pojmu basic skills, cez competences až po konečné key competences. Termínom basic skills (základné zručnosti), poprípade tzv. life alebo survival skills (životne dôležité zručnosti), sa zvyčajne označovali zručnosti späté s čítaním, písaním a počítaním. Práve pre svoj vel’mi úzky rozsah bol tento pojem nahradený pojmom competence. $\mathrm{V}$ kurikulách európskych krajín sa popri pojmu klúčové kompetencie (nemecká a flámska komunita Belgicka, Nemecko, Rakúsko, Portugalsko, Luxembursko) objavujú aj iné pojmy, ktoré bud' bližšie špecifikujú, alebo úplne nahrádzajú pojem klúčové kompetencie. Ako rozlíšenie na predmetové a prierezové kompetencie (francúzska komunita Belgicka), základné kompetencie (Nemecko, Portugalsko, Luxembursko), klúčové kvalifikácie (Nemecko) alebo klúčové zručnosti, základné zručnosti (Vel'ká Británia). Aj v týchto krajinách je $\mathrm{v}$ súčasnosti silný tlak na zjednotenie terminológie $\mathrm{v}$ zmysle používania pojmu klúčové kompetencie. Podl’a Walterovej (2004), je „pojem kompetencia“ definovaný rôznym spôsobom v rôznych kontextoch. Podstatou je dôraz na schopnost' konat' aktívne, na rozdiel od tradičného modelu, založeného na demonštrácii vedomostí. Byt' kompetentný znamená vediet' sa vyrovnat' s kritickými, neprehl'adnými, spletitými a nepredvídanými situáciami. Belz a Siegrist (2001), chápu klúčové kompetencie ako kompetencie, ktoré presahujú hranice jednotlivých odborností, navzájom sa ovplyvňujú a pri ich rozvoji zohráva dôležitú úlohu reflexia a kritické uvažovanie. Bagalová (2005), považuje za klúčové kompetencie len najdôležitejšie univerzálne aplikovatel'né multifunkčné kompetencie - t.j. všeobecné nadpredmetové kompetencie a najvšeobecnejšie kompetencie založené na predmete, ale aplikovatel'né $\mathrm{v}$ d’alších predmetoch, oblastiach poznávania a $\mathrm{v}$ živote. Vymedzuje nasledovné oblasti klúčových kompetencií: kompetencie kognitívne, metodologické a funkčné, sociálne, komunikačné, občianske, personálne. Klúčové kompetencie sa chápu ako najdôležitejšie, najuniverzálnejšie z celého radu kompetencií osobnosti. Ide o „prenosný a multifunkčný, univerzálne použitel'ný súbor vedomostí, zručností, postojov a hodnôt, ako uvádza vo svojich štúdiách spomínaná autorka a musia byt' použitel'né v rôznych kontextoch a situáciách, ktoré potrebuje každý jednotlivec pre svoje osobné naplnenie a rozvoj, pre zapojenie sa do spoločnosti a úspešnú zamestnanost"“. Pri vymedzení pojmu klúčových kompetencií sme využili skúsenosti z medzinárodných porovnávacích štúdií (PISA, PIRLS...), 
ale skúmali sme aj štúdie OECD, projekt Milénium, návrh Ministerstva školstva SR, Európskej únie a systémy Českej republiky.

Sundberg a kol.(1978), všetko psychológovia, definovali klúčové kompetencie ako: „osobné charakteristiky (vedomosti, zručnosti a postoje), ktoré vedú $\mathrm{k}$ adaptívnym výkonom jedinca, schval'ovaných zo strany preňho významných typov prostredí.“ Tu možno poukázat' na rôzne chápanie klúčových kompetencií. Teda, že pre niekoho istá kompetencia môže byt' klúčová, ale pre iných nemusí, pretože ich prostredie to nevyžaduje. Kl'účové kompetencie sú nielen závislé od situácie, ale aj od prostredia.

M. Romainville (1996), ako pedagóg pripomína, že termín compétence (kompetencia) sa pôvodne používal v kontexte odbornej prípravy a označoval ,...schopnost' (spôsobilost') vykonávat' určitú úlohu...". Potom čo prenikol do sféry všeobecného vzdelávania, značí určitú „schopnost"“ či „potenciál“ účinne jednat' v danom kontexte. Dnes už nemá význam samotný, izolovaný poznatok, ale jeho uplatnenie, využitie.

Podl'a Tureka (2002), sú klúčové kompetencie,najdôležitejšie z množiny kompetencií. Sú vhodné na riešenie celého radu väčšinou nepredvídatel'ných problémov, ktoré umožňujú jedincovi úspešne sa vyrovnat' $\mathrm{s}$ rýchlymi zmenami $\mathrm{v}$ práci, $\mathrm{v}$ osobnom i spoločenskom živote“. Autor navrhuje tento systém klúčových kompetencií: informačné, učebné, kognitívne, interpersonálne, komunikačné, personálne.

Pojem klúčová kompetencia najlepšie vystihuje behaviorálna definícia: „Klúčová kompetencia je správanie (činnost' alebo komplex činností), ktoré charakterizuje vynikajúci výkon v niektorej oblasti činnosti." Tento opis poukazuje iba na tie činnosti (správanie) a zručnosti, ktoré sú typické pre vynikajúci výkon. Neobsahuje v sebe explicitne vedomosti, ale zahŕňa v sebe aplikáciu príslušných vedomostí, ktoré sú predpokladom a nevyhnutné pre dosahovanie vynikajúcich výkonov a výsledkov. Treba uviest', že z hl'adiska frekvencie, sa v súčasnosti a najmä $\mathrm{v}$ školských podmienkach, najviac používa termín klúčové kompetencie. Tento termín je jednoznačne uprednostňovaný pred akýmikol'vek inými pojmami, a to s ohl'adom na kompatibilitu pojmov v medzinárodnom meradle a taktiež preto, že svojim rozsahom ako jediný zo všetkých uvedených pojmov, pokrýva ako vedomosti, zručnosti, schopnosti, tak i postoje a hodnoty.

Jadrom pojmu kompetencia je pojem zručnost'. Švec (1998), definuje zručnost' ako „na báze schopností, učením a nácvikom získaná pripravenost' $\mathrm{k}$ správnemu, rýchlemu a úspornému plneniu určitých úloh". Ako uvádza Švec, nejde o celkom správne a výstižné označenie, pretože zručnost' evokuje skôr manuálnu činnost'. Navrhuje preto používat' pojem spôsobnost'(spôsobilost'), ktorý definuje ako „operatívnu schopnost' (postupne, plynule, pohotovo, l'ahko, presne a úsporne) uskutočnit' a úplne dokončit' sled kognitívnych alebo mimokognitívnych úkonov, ktoré je žiadúce praktikovat' (opakovat', upevňovat', cvičit'), aby sa vykonali účinne“. Vytvorit model klúčových kompetencií v edukácii nie je jednoduché. Záleží od prístupov jednotlivých autorov, od ciel’ov a kritérií, ktorým majú dané modely slúžit'. Napriek mnohým terminologickým problémom, snahám o zjednotenie, výskumom v danej oblasti, doposial' neexistuje jednotné vymedzenie pojmu kompetencia.

\section{Základné východiska, nastolenie riešenej problematiky}

Technika v spoločnosti zohráva čím d’alej, tým dôležitejšiu úlohu. Svoj význam nezvýrazňuje len $\mathrm{v}$ oblastiach, $\mathrm{v}$ ktorých predtým dlhý čas pôsobila, ale postupne preniká 
i do sfér l'udskej činnosti, ktoré neboli typickými miestami jej pôsobenia. Spojenie vyučovania s prácou sa prejavuje nielen tým, že sa vo vyučovaní všeobecne vzdelávacích predmetov vysvetl'ujú vedecké základy pracovného procesu, ale že sa v práci uplatňujú skôr už osvojené vedecké znalosti. Samostatná práca sa stáva dôležitým prostriedkom $\mathrm{k}$ prebudeniu túžby žiakov po vedomostiach a prameňom nových vedomostí. Rozvoj pracovno - technických zručnosti značne ul'ahčuje žiakom osvojovanie pojmov a činí vedomosti konkrétnymi a účinnejšími. Hlavným motivačným dôvodom pre štúdium tejto problematiky je snaha pri hl'adaní ciest k novej, efektívnejšej, pre žiakov prítažlivejšej a pre ich osobné a profesionálne uplatnenie užitočnejšej školy, ktorá nechce stratit' kontinuitu $\mathrm{s}$ vývojom vzdelávania $\mathrm{v}$ danej oblasti. Je nutné prispôsobovat' sa meniacim sa požiadavkám doby. Po prvýkrát sa $\mathrm{v}$ našich vzdelávacích programoch (pozri Milénium) objavujú požiadavky na výsledky vzdelávania žiakov, ktoré nevychádzajú zo špecifík jednotlivých predmetov, ale dotýkajú sa univerzálnejšich znalostí, schopností, zručností a postojov, ktoré bežne potrebujeme vo svojom živote a ktoré sú využitel’né v mnohých životných i pracovných situáciách. Tieto sú označené ako klúǔové kompetencie.

Predmet technika na základnej škole vytvára vhodné predpoklady, aby boli u žiakov vytvorené základy poznania skutočnosti. Umožňuje to, predovšetkým zameranie a technická povaha predmetu. Spracovanie širokej škály technických materiálov, poznávanie ich základných vlastností, oboznamovanie sa s pracovnými nástrojmi a pomôckami umožňuje (pri potrebnom počte hodín), dosiahnutie primeraných pracovných vedomostí, zručností a návykov. Základom takto orientovanej výučby predmetu, má byt' pracovný proces, ktorý pri správnom vedení učitel’om, umožňuje aktívnu činnost' žiakov a prvotné poznávanie technických vzt’ahov. Ide o poznávanie vzt’ahov medzi materiálom, zvoleným spôsobom práce, nástrojom, pracovnými podmienkami a bezpečnost'ou práce. Je potrebné dosiahnut, aby si žiaci dané vzt’ahy uvedomovali a učili sa ich tvorivo vo svojej práci využívat'. Výsledkom takejto činnosti je, že aktivita žiakov sa zvyšuje, podnecuje sa ich fantázia, rozvíja samostatná práca žiakov, práca v tíme, ako aj základné zložky technického myslenia. Rozvoj uvádzaných zručnosti a schopnosti, vyžaduje vo vyučovaní zo strany učitel’a, tvorbu a aplikáciu takých vzdelávacích úloh, ktoré umožnia žiakovi vol'nejšie narábat's osvojenými poznatkami, využívat' ich v nových kontextoch a pri riešení nových neznámych problémov.

\section{Analýza rozvoja vybraných kl’účových kompetencií}

Jednou z podstatných profesionálnych spôsobilosti učitela je tvorba takých úloh a metodických postupov, ktoré napomáhajú k vytváraniu ich kompetencií. Tvorivo zameraný učitel' posilňuje interakcie so žiakmi, pri optimálnom vzt’ahu k žiakom. Podporuje dôveru každého žiaka vo svoje schopnosti, akceptuje každého žiaka, pozorne počúva, prijíma názory, pocity žiaka. Základom úspešného vyučovania $\mathrm{v}$ našich školách má byt' učitel', tvorivý žiak a vytváranie podmienok pre rozvoj kompetencií a možné uplatnenie rôznych druhov tvorivých činností vo vyučovaní. Učitel' sa má snažit prácu a výučbu organizovat' tak, aby žiacke vedomosti, zručnosti a návyky, boli výsledkom ich samostatnej práce, vlastných pracovných činnosti, výsledkom vlastného myslenia. Určitými kritériami takejto činnosti v predmete technika sú napríklad:

- nový prístup k tvárno-technickému zobrazovaniu skutočnosti,

- novost', nápaditost', sebavyjadrenie v spracovaní témy, 
- využitie nových, progresívnych foriem práce,

- $\quad$ originalita techniky, použitie materiálu a nové spracovanie detailov,

- $\quad$ využívanie širokých možnosti IT technológií.

Základom hodín predmetu technika má byt' pracovný proces, ktorý pri správnom vedení, umožňuje aktívnu činnost' žiakov a prvotné poznávanie technických vzt'ahov a súvislosti. Pozorovanie vyučovacieho procesu by nás malo priviest' k novým záverom, že vyučovanie nie je len jednostranné pôsobenie učitel'a na žiakov, ale žiaci svojim prístupom k vyučovaniu, učeniu, poznatkami a úrovňou vedomostí, významne ovplyvňujú pedagogické činnosti učitel'a. Avšak ani toto bipolárne chápanie ešte nevystihuje zložitost' vyučovacieho procesu. Ten nie je charakterizovaný iba vzt’ahmi učitel’ - žiak. Do vyučovacieho procesu „vstupuje“ a ovplyvňuje ho celý rad činitel'ov. Súčasná moderná didaktika zdôrazňuje skúmanie a rešpektovanie všetkých týchto činitel'ov $\mathrm{v}$ jednote, pretože navzájom súvisia - ciele s obsahom, subjekt (učitel') s objektom (žiak), vzdelanie s výchovou, teória s praxou. Takto organizovaná interaktivna forma vyučovacieho procesu, je formou vyučovania, ktorá sa snaží skvalitnit' podmienky $\mathrm{v}$ najnovších trendoch vyučovania, aj za aktívneho využitia informačných technológií, ako je internet, interaktívna tabula, tablet s prídavným softvérom prispôsobeným školským podmienkam. Takto vedený vyučovací proces, nie je iba jednoduchým odovzdávaním hotových poznatkov, ale mení sa na usilovné hladanie a individuálne poznávanie nových faktov, odhal'ovanie súvislostí a zákonitostí.

Klúčcové kompetencie u žiakov, sú najdôležitejšie z množiny kompetencií. Sú vhodné na riešenie celého radu väčšinou nepredvídatel'ných problémov, ktoré umožňujú žiakovi úspešne sa vyrovnat' s rýchlymi zmenami $v$ škole, je to schopnost', ktorú charakterizuje vynikajúci výkon v niektorej oblasti činnosti žiaka. Medzi vybrané kompetencie žiakov v predmete technika patria, charakteristické prvky činnosti, ktoré sa vyskytujú ovel’a častejšie a dôslednejšie pri dosahovaní vel'mi dobrých výkonov. Na základe výskumu realizovanom $\mathrm{v}$ rámci projektov na našom pracovisku, ktoré boli venované tvorbe a zist'ovaniu klúčcových kompetencií s použitím vybraných technických prostriedkov a spôsobom merania klúčových kompetencií, môžeme medzi najdôležitejšie vybraté kategórie klúčových kompetencií, zaradit' tieto:

- komunikačné schopnosti a spôsobilosti žiakov, to znamená ústne a písomne sa vyjadrovat', vysvetl'ovat', čítat' $\mathrm{s}$ porozumením, vyhl'adávat', uchovávat', komunikovat' a používat' informácie,

- interpersonálne schopnosti a spôsobilosti žiakov, čo znamená, pracovat' v tíme, harmonicky spolupracovat', radit' sa navzájom, spoločne riešit' úlohy,

- informačné schopnosti a spôsobilosti žiakov, čo znamená, informácie kriticky hodnotit', používat' na riešenie problému, vyjadrovat' sa graficky, hodnotit' obsah, riešit' úlohu spoločne,

- personálne schopnosti a spôsobilosti žiakov, obsahujú spôsobilosti sebazdokonal'ovania, výkonnosti, schopnosti samostatne sa vzdelávat', kontrolovat' sa, regulovat' svoje správanie, zodpovedat' za výsledok,

- učebné schopnosti a spôsobilosti žiakov, obsahujú spôsobilosti riešit' problém, motivovat' seba aj druhých, kriticky hodnotit' výsledky, pozitívne mysliet', 
- kognitívne schopnosti a spôsobilosti žiakov, sústred’ujú sa na kritické myslenie a hodnotenie, hodnotenie textu, chýbajúce údaje, kriticky hodnotit' vypracovanie úloh, individuálne formulovat' závery.

Zo získaných záverov výskumu možno uviest', že vytváranie týchto vybraných klúčových kompetencií $\mathrm{v}$ predmete technika, výrazne ovplyvňuje samotná vhodne nasmerovaná činnost' žiaka. Úlohou učitel'a techniky je nielen tieto schopnosti žiakov rozvijat', ale aj objektívne hodnotit'. Tvorivý potenciál žiakov môže byt' vel'ký, ale ak nemá podmienky, aby sa prejavil, ostáva len možnost'ou a neprináša nič nové, užitočné. Pre pedagogickú prax $\mathrm{z}$ toho vyplýva potreba neustále sledovat' záujmy žiakov, skúmat' vo vyučovacom procese nové metódy a postupy, stále účinnejšie pôsobit' na spôsoby práce žiakov.

\section{Priebeh a závery $\mathrm{z}$ realizovanej vedecko výskumnej činnosti}

$\mathrm{V}$ nasledujúcej časti štúdie, sa zaoberáme úlohami a čiastkovými výsledkami realizovaného výskumu na základných školách. Jednou z hlavných úloh bolo overit' funkčnosti vypracovaných meracích nástrojov (pozorovací hárok), k čomu bolo nevyhnutné vymedzit' a stanovit' pozorované javy a zaznamenat' ich výskyt.

\section{Projekt experimentálneho výskumu}

Aby bolo možné do výučby a prípravy budúcich učitel’ov Techniky pre nižší stupeň stredného vzdelávania zaviest' aj modul obsahovo zameraný na rozvoj spôsobilosti žiakov, bolo potrebné vytvárat' také modely a stratégie výučby, ktoré s využitím interaktívneho prostredia ( IT tabule) napomáhajú vytvárat nové prostredie a prispievat' $\mathrm{k}$ rozvoju vybraných klúčcových kompetencií žiakov. Bolo potrebné uskutočnit' štúdium odbornej literatúry a publikácií zameraných na predmetný problém. Na základe analýzy odborných prameňov a zistení bola navrhnutá prvotná východisková štruktúra a rámcový obsah teoretickej a praktickej časti budúceho diela, t.j. spracovanej metodiky.

$\mathrm{K}$ tomu, aby bolo možné jasne, konkrétne a jednoznačne vymedzit' a stanovit' pozorované javy a zaznamenat' ich výskyt, bolo najskôr potrebné:

- vel'mi dôkladne analyzovat' vzdelávacie obsahy pre vybranú tému vyučovania a súčasne zvažovat' i navrhovat' pracovné úlohy pre žiakov (v predvádzacom zošite a v pracovnom liste žiaka) tak, aby vo vymedzenom čase (1 vyučovacia hodina) bol dostatočný priestor na realizáciu úloh,

- Vytypovat' zároveň z množiny klúčových zručností adekvátne klúčové zručnosti tak, aby pokrývali viacero skupín klúčových zručností (napr. informačné, učebné, personálne...),

- upravit pracovné úlohy pre žiakov tak, aby vytvárali jasný priestor na uplatňovanie (výskyt) vybraných kl'účových zručností počas učebnej činnosti učitel’a a žiaka a aby takto upravené pracovné úlohy rozvíjali vybrané klúčové zručnosti žiakov,

- dostatočne $\mathrm{v}$ predstihu pred priebehom vlastného pozorovania, pozorne naštudovat' predvádzací zošit a pripravené pracovné listy použité na hodinách, 
- $\quad$ pripravit' si vhodné miesto na pozorovanie priamo v triede, kde bude prebiehat' hodina, aby bolo možné nerušene pozorovat' a identifikovat' výskyt samotných javov.

Na základe rozboru a analýzy vyučovacích hodín techniky na ZŠ, z celkového balíka zručnosti boli vybrané najvhodnejšie, uvedené $\mathrm{v}$ príslušnej tabul'ke, $\mathrm{v}$ ktorej je už zaznamenaný aj výskyt javov zistený pozorovaním.

Pre učebný predmet technika z množiny kl'účových zručností sme vybrali tie, ktoré uvádza tabul'ka 1

\begin{tabular}{|l|l|}
\hline Kategória kl'účovej zručnosti & Vybraná kl'účová zručnost' \\
\hline Interpersonálna & pracovat'v tíme \\
\hline & interpersonálne vzt'ahy \\
\hline Informačná & informácie kriticky hodnotit' a použit' na riešenie pro \\
\hline & vyjadrovat' sa graficky \\
\hline Komunikačná & č́tat's porozumením \\
\hline & vyjadrovat' sa ústne \\
\hline Personálna & vyjadrovat' sa písomne \\
\hline & kontrolovat' svoje správanie \\
\hline & zodpovednost' za výsledok \\
\hline Učebná & čestnost' a zodpovednost' \\
\hline & sebahodnotenie \\
\hline Kognitívna & motivovat' seba aj druhých \\
\hline & riešit' problém \\
\hline & kritické myslenie a hodnotenie \\
\hline
\end{tabular}

\section{Tab. ̌́. 1: Vybrané klúčové zručnosti}

Možnost' prijat' záver, že celá, ale najmä praktická čast' metodiky je odborne, didakticky i funkčne vhodne a správne vypracovaná, t. j. modely a stratégie vyučovacích hodín, predvádzacie zošity pre IT a pracovné listy žiakov sú v školskej praxi plne použitel’né a prinášajú očakávaný efekt, umožnil vo vybraných školách počas výučby jednotlivých učebných obsahov, realizovaný experimentálny výskum.

Objektom výskumu bola vybraná vzorka žiakov 5. až 9. ročníkov vybraných ZŠ $\mathrm{v}$ prešovskom, nitrianskom a banskobystrickom regióne. $\mathrm{K}$ výberu vzoriek čiastkových výskumov, pristúpil výskumný tím, pozostávajúci z desiatich pracovníkov katedier fakúlt v Prešove, B. Bystrici a Nitre, pripravujúcich budúcich učitel’ov techniky. Z hl'adiska výberu vzorky výskumu, výskumníci pre výber uplatnili stratifikovaný zámerný výber. Celkový výskum prebehol na 18 základných školách, pre 15 vybraných rozpracovaných tém a do výskumu bolo zapojených $\mathrm{v}$ jednotlivých triedach 196 pozorovaných žiakov. 


\section{Ciele výskumu}

Hlavným ciel'om výskumu bolo zistit', či navrhnuté modely a stratégie výučby učebného predmetu technika aplikované počas výučby vo vybraných ročníkoch a téme vyučovacích hodín $\mathrm{v}$ spojení $\mathrm{s}$ využitím interaktívneho prostredia (IT tabule), prispejú k rozvíjaniu vybraných kl’účových kompetencií žiakov.

Čiastkovými ciel'mi výskumu boli:

- overenie funkčnosti vypracovaných meracích nástrojov (pozorovací hárok),

- overenie vhodnosti a použitel'nosti vypracovaných modelov, stratégií výučby,

- overenie učebných pomôcok.

\section{Hypotézy výskumu}

Základnou a vzhl'adom na dosial' neprebádanú problematiku, pracovnou hypotézou výskumu bola hlavná hypotéza: Predpokladáme, že navrhnuté modely a stratégie výučby aplikované vo výučbe učebných predmetov, počas experimentálnej výučby vo vybraných ročníkoch 5. až 9 . ZŠ a vybraných témach vyučovacích hodín, v spojení s využitím IT vytvoria podmienky, ktoré prispejú k rozvíjaniu vybraných kl’účových kompetencií žiakov. Zámerom bolo zistit' účinok nezávisle premennej, vyučovanie s použitím IT a pracovných listov žiakov (príčina) na závisle premennú rozvoj vybraných kl'účových kompetencií (dôsledok).

\section{Výsledky čiastkového výskumu}

Nakol'ko v tomto príspevku vzhl'adom na rozsah výsledkov výskumu, tieto nie je možné uviest', v nasledujúcej časti uvádzame príklad vyhodnotenia vybranej ZŠ, tried 7.A a 7.B, pre zvolenú tému Myšlienka-konštrukcia-výroba-využitie, ktorí je súčast'ou celkových výsledkov výskumu. Výsledky čiastkového výskumu sú v nasledujúcej časti spracované podl'a jednotlivých tried základnej školy sumárne, pričom sú zoradené chronologicky podl’a termínov konania čiastkových výskumných aktivít v základnej škole, v ktorej boli pozorovania uskutočnené. Učitelia techniky vo vybranej základnej škole vyučovali podl'a vopred vypracovanej metodiky výučby, ktorá pre vybranú tému vyučovacej hodiny, bola vopred s nimi konzultovaná. Pozorovatel' realizoval pred každým pozorovaním, dohovor s príslušným vyučujúcim. V priebehu vyučovacej hodiny sa pozorovatel' správal tak, aby nemal žiaden vplyv na priebeh vyučovacej hodiny a žiakov. Potrebné informácie o vybraných dvojiciach zaznamenával pozorovatel' do pozorovacích hárkov. Pre všetky tímy žiakov $\mathrm{v}$ triede boli na školské lavice vopred uložené pracovné listy P1 až P4. Žiaci, pred začiatkom používania pracovných listov, na pokyn učitel'a, na určené miesto v P1 napísali triedu a ročník. Práca žiakov v pracovných listoch, bola anonymná. Po skončení vyučovacej hodiny učitel' a pozorovatel' pracovné listy zozbierali a pozorovatel' vzal výskumný materiál na jeho d'alšie spracovanie.

Metodika výučby a práca žiakov s pracovnými listami P1 až P4: Pracovné listy P1 až P4 sú obsahom rovnaké, sú to teda na bežnom papieri vytlačené stránky predvádzacieho zošita (snímky) ZP 7 až ZP 10. Pri postupnom prezentovaní a zadávaní úloh učitel' na interaktívnej tabuli zobrazoval jednotlivé stránky predvádzacieho zošita a žiaci mali možnost' sledovat' zadania úloh na interaktívnej tabuli. Toto sa týkalo pracovných zošitov ZP1-ZP6, od úvodného zošita cez zopakovanie učiva, motiváciu až po riadený rozhovor. V stránkach 
predvádzacieho zošita ZP7-ZP10 prebiehala už práca súbežne na interaktívnej tabuli, ako aj vo svojich pracovných listoch. Podl'a pokynov v metodike, žiaci riešili jednotlivé úlohy bud' samostatne, alebo vo dvojiciach, alebo vyvolaný žiak riešil niektorú zo stanovených úloh po skončení samostatnej alebo tímovej práce žiakov priamo na interaktívnej tabuli, ako kontrola práce $\mathrm{v}$ pracovných listoch.

S ciel'om zabezpečit' čo najvyššiu mieru zhodnosti a jednotnosti výsledkov pozorovaní, v rámci riešitel'ského kolektívu bola prijatá posudzovacia škála, aby boli jednotlivé pozorované vlastnosti (javy) postrehované pomocou stupňov, ktoré zodpovedajú ich rôznej intenzite. Pozorovatel' určoval intenzitu vlastnosti označením jej polohy + (plus) alebo (mínus), prípadne áno- nie priamo v pozorovacím hárku. V našom prípade bola použitá nasledujúca, zatial' len dvojstupňová škála s krajnými intenzitami (stavmi) z dôvodu zjednotenia zaznamenávania výsledkov pozorovaní u všetkých pozorovatel'ov (riešitel'ov projektu).

Výsledky pozorovaní vo vybranej ZŠ počas výučby témy vyučovacej hodiny Myšlienka-konštrukcia-výroba-využitie, uvádza tabul'ka 2

\begin{tabular}{|c|c|c|c|c|c|c|c|}
\hline \multirow[b]{2}{*}{$\begin{array}{l}\text { Kategória } \\
\text { kl'účovej } \\
\text { zručnosti }\end{array}$} & \multirow[b]{2}{*}{$\begin{array}{l}\text { Vybraná kl'účová zručnost' } \\
\text { R (riadok) / úloha } \\
\text { (pozorovaný jav) }\end{array}$} & \multirow[b]{2}{*}{$\begin{array}{l}\text { Prac } \\
\text { ovný } \\
\text { list } \\
\text { číslo }\end{array}$} & \multicolumn{2}{|c|}{$\begin{array}{c}\text { ZŠ,7. ročník } \\
\text { (7. A) }\end{array}$} & \multicolumn{2}{|c|}{$\begin{array}{c}\text { ZŠ ,7.ročník } \\
\text { (7. B) }\end{array}$} & \multirow[b]{2}{*}{$\begin{array}{l}\text { N } \\
\text { (rie } \\
\text { šeni } \\
\text { e) } \\
\text { áno } \\
\text { / nie } \\
\end{array}$} \\
\hline & & & $\begin{array}{l}\text { Sku } \\
\text { pina } \\
\text { č. } 1 \\
\text { (diev } \\
\text { čatá) }\end{array}$ & $\begin{array}{l}\text { Skup } \\
\text { ina č. } \\
2 \\
\text { (chla } \\
\text { pci) }\end{array}$ & $\begin{array}{l}\text { Skupi } \\
\text { na č. } \\
1 \\
\text { (dievč } \\
\text { atá) }\end{array}$ & $\begin{array}{l}\text { Skupi } \\
\text { na č. } \\
2 \\
\text { (chlap } \\
\text { ci) }\end{array}$ & \\
\hline \multirow[t]{2}{*}{$\begin{array}{c}\text { Interperson } \\
\text { álna }\end{array}$} & $\begin{array}{l}\text { pracovat'v tíme } \\
\text { R1/úloha - poradit' sa } \\
\text { k prečítanému textu - v tíme } \\
\text { harmonicky spolupracovat' }\end{array}$ & $\begin{array}{l}\mathrm{P} 1 / \mathrm{Z} \\
\mathrm{P}-6\end{array}$ & $\begin{array}{l}2 \mathrm{x} \\
\text { áno }\end{array}$ & nie & $\begin{array}{l}2 \mathrm{x} \\
\text { áno }\end{array}$ & $\begin{array}{l}2 \mathrm{x} \\
\text { áno }\end{array}$ & $6 / 2$ \\
\hline & $\begin{array}{l}\text { R2/interpersonálne vzt'ahy } \\
\text { - harmonické } \\
\text { R3/spolu - pracovat' v tíme } \\
\text {,pokojná atmosféra }\end{array}$ & $\begin{array}{l}\text { P3/ } \\
\text { ZP-9 } \\
\text { P4/Z } \\
\text { P-10 }\end{array}$ & $\begin{array}{l}\text { áno } \\
\text { áno }\end{array}$ & $\begin{array}{l}\text { áno } \\
\text { áno }\end{array}$ & $\begin{array}{l}\text { áno } \\
\text { áno }\end{array}$ & $\begin{array}{l}\text { áno } \\
\text { áno }\end{array}$ & $\begin{array}{l}8 / 0 \\
8 / 0\end{array}$ \\
\hline \multirow[t]{2}{*}{ Informačná } & $\begin{array}{l}\text { informácie kriticky } \\
\text { hodnotit' a použit' na } \\
\text { riešenie problému } \\
\text { R5/úloha - spolu hodnotit' } \\
\text { obsah textu, úlohu riešit' - } \\
\text { vyjadrit' sa graficky doplnit' } \\
\text { názvoslovie k operáciám }\end{array}$ & $\begin{array}{l}\text { P3/Z } \\
\text { P-9 }\end{array}$ & $\begin{array}{c}2 \mathrm{x} \\
\text { áno }\end{array}$ & $\begin{array}{c}2 \mathrm{x} \\
\text { áno }\end{array}$ & $\begin{array}{c}2 \mathrm{x} \\
\text { áno }\end{array}$ & $\begin{array}{c}2 \mathrm{x} \\
\text { áno }\end{array}$ & $8 / 0$ \\
\hline & $\begin{array}{l}\text { R6/vyjadrovat' sa graficky - } \\
\text { úloha - sám zoradit' operácie } \\
\text { v správnom poradí }\end{array}$ & $\begin{array}{l}\mathrm{P} 4 / \mathrm{Z} \\
\mathrm{P}-10\end{array}$ & áno & áno & áno & $\begin{array}{c}\text { áno/ni } \\
\mathrm{e}\end{array}$ & $7 / 1$ \\
\hline$\underset{\text { ná }}{\text { Komunikač }}$ & $\begin{array}{l}\text { čitat's porozumením } \\
\text { R7/úloha - spolu } \\
\text { porozumiet' textu } \\
\text { R8/úloha-čítat', pomoc } \\
\text { z predchádzajúceho textu }\end{array}$ & $\begin{array}{l}\mathrm{P} 1 / \mathrm{Z} \\
\mathrm{P}-7\end{array}$ & $\begin{array}{l}2 \mathrm{x} \\
\text { áno } \\
\text { áno }\end{array}$ & $\begin{array}{c}\text { 2xán } \\
\text { o } \\
\text { nie }\end{array}$ & $\begin{array}{l}\text { 2xáno } \\
\text { áno }\end{array}$ & $\begin{array}{c}2 \mathrm{x} \\
\text { áno } \\
\text { nie }\end{array}$ & $4 / 4$ \\
\hline
\end{tabular}




\begin{tabular}{|c|c|c|c|c|c|c|c|}
\hline & $\begin{array}{l}\text { pochopit' názvy, priradit' } \\
\text { čísla k obrázkom }\end{array}$ & $\begin{array}{l}\mathrm{P} 1 / \mathrm{Z} \\
\mathrm{P}-5\end{array}$ & & & & & \\
\hline & $\begin{array}{l}\text { vyjadrovat' sa ústne } \\
\text { R9/úloha - zopakovanie } \\
\text { predchádzajúceho učiva }\end{array}$ & $\begin{array}{l}\mathrm{P} 1 / \mathrm{Z} \\
\mathrm{P}-4\end{array}$ & áno & áno & áno & nie & $6 / 2$ \\
\hline & $\begin{array}{l}\text { vyjadrovat' sa písomne } \\
\text { R/10 úloha - sám dopísat' } \\
\text { chýbajúci text } \\
\text { R11/úloha }- \text { spoločne } \\
\text { dopísat' na tabulu }\end{array}$ & $\begin{array}{l}\text { P2,3/ } \\
\text { ZP- } \\
10 \\
\text { P3/Z } \\
\text { P-10 }\end{array}$ & $\begin{array}{l}\text { áno } \\
\text { áno }\end{array}$ & $\begin{array}{l}\text { áno } \\
\text { nie }\end{array}$ & $\begin{array}{l}\text { áno } \\
\text { nie }\end{array}$ & $\begin{array}{l}\text { áno } \\
\text { áno }\end{array}$ & $\begin{array}{l}6 / 2 \\
4 / 4\end{array}$ \\
\hline \multirow[t]{6}{*}{ Personálna } & $\begin{array}{l}\text { kontrolovat' svoje správanie } \\
\text { R12/samostatná práca bez } \\
\text { vyrušovania }\end{array}$ & $\begin{array}{l}\mathrm{P} 1 / \mathrm{Z} \\
\mathrm{P}-7\end{array}$ & áno & áno & nie & nie & $4 / 4$ \\
\hline & $\begin{array}{l}\text { zodpovednost' za výsledok } \\
\text { R13/úloha - sám } \\
\text { skontrolovat' správnost' } \\
\text { riešení úloh spolužiakovi }\end{array}$ & $\begin{array}{l}\mathrm{P} 1 / \mathrm{Z} \\
\mathrm{P}-7\end{array}$ & áno & $\mathrm{Nie}$ & áno & nie & $4 / 4$ \\
\hline & $\begin{array}{l}\text { čestnost'a zodpovednost' } \\
\text { R14/úloha - sám správne } \\
\text { pridelit' a spočítat' získané } \\
\text { body }\end{array}$ & $\begin{array}{l}\mathrm{P} 3 / \mathrm{Z} \\
\mathrm{P}-9\end{array}$ & áno & áno & áno & áno & $8 / 0$ \\
\hline & $\begin{array}{l}\text { R15/úloha - sám } \\
\text { kontrolovat' riešenia a } \\
\text { správne pridelit', spočítat' a } \\
\text { zapísat' body }\end{array}$ & $\begin{array}{l}\mathrm{P} 4 / \mathrm{Z} \\
\mathrm{P}-10\end{array}$ & áno & áno & áno & áno & $8 / 0$ \\
\hline & $\begin{array}{l}\text { R16/úloha - spolu vytvorit } \\
\text { celkový súčet získaných } \\
\text { bodov za tím }\end{array}$ & $\begin{array}{l}\mathrm{P} 4 / \mathrm{Z} \\
\mathrm{P}-10\end{array}$ & $\begin{array}{c}\text { nerie } \\
\text { šili }\end{array}$ & $\begin{array}{c}\text { nerieš } \\
\text { ili }\end{array}$ & $\begin{array}{l}\text { nerieši } \\
\text { li }\end{array}$ & $\begin{array}{l}\text { nerieši } \\
\text { li }\end{array}$ & $8 \mathrm{~N}$ \\
\hline & $\begin{array}{l}\text { R17a/úloha - hodnotit' seba } \\
\text { samých }\end{array}$ & $\begin{array}{l}\mathrm{P} 4 / \mathrm{Z} \\
\mathrm{P}-10\end{array}$ & áno & áno & nie & nie & $4 / 4$ \\
\hline \multirow[t]{2}{*}{ Učebná } & $\begin{array}{l}\text { motivovat' seba aj druhých } \\
\text { R18/úloha - pozitívne } \\
\text { nabádat'k spolupráci v tíme, } \\
\text { hodnotit' spoločne kriticky } \\
\text { výsledky }\end{array}$ & $\begin{array}{l}\mathrm{P} 2 \\
\text { /ZP- } \\
8\end{array}$ & $\begin{array}{c}2 \mathrm{x} \\
\text { áno }\end{array}$ & $\begin{array}{l}2 \mathrm{x} \\
\text { nie }\end{array}$ & $\begin{array}{l}2 \mathrm{x} \\
\text { áno }\end{array}$ & $\begin{array}{l}2 \mathrm{x} \\
\text { áno }\end{array}$ & $6 / 2$ \\
\hline & $\begin{array}{l}\text { riešit' problém } \\
\mathrm{R} 19 / \text { úloha }- \text { sám }-\mathrm{z} \\
\text { vybraných súčiastok } \\
\text { nakreslit' obraz }\end{array}$ & $\begin{array}{l}\mathrm{P} 3 / \mathrm{Z} \\
\mathrm{P}-8\end{array}$ & áno & áno & nie & áno & $6 / 2$ \\
\hline
\end{tabular}




\begin{tabular}{|c|c|c|c|c|c|c|c|}
\hline Kognitívna & $\begin{array}{l}\text { kritické myslenie } \\
\text { a hodnotenie } \\
\text { R20/úloha - spolu - } \\
\text { hodnotit' obsah textu, } \\
\text { doplnit' chýbajúce slová, } \\
\text { hodnotit' } \\
\text { R21/úloha - sám - hodnotit' } \\
\text { názvy/čísla/ priradené } \\
\text { obrázkom, kriticky } \\
\text { zhodnotit' vypracovanie } \\
\text { R22/úloha - sám - pridelit' } \\
\text { náradie k operáciám } \\
\text { R23/úloha - sám } \\
\text { formulovat' záver, } \\
\text { individuálne }\end{array}$ & $\begin{array}{l}\text { P3/Z } \\
\text { P-9 } \\
\text { P4/Z } \\
\text { P-10 } \\
\text { P3/Z } \\
\text { P-9 } \\
\\
\text { ZP9, } \\
10\end{array}$ & $\begin{array}{l}2 \mathrm{x} \\
\text { áno } \\
\text { áno } \\
\text { nerie } \\
\text { šili }\end{array}$ & $\begin{array}{l}2 \mathrm{x} \\
\text { áno } \\
\text { áno } \\
\text { nerieš } \\
\text { ili }\end{array}$ & $\begin{array}{l}\text { nie/án } \\
\text { o } \\
\text { áno }\end{array}$ & $\begin{array}{l}\text { 2x nie } \\
\text { áno }\end{array}$ & $\begin{array}{l}7 / 3 \\
8 / 0\end{array}$ \\
\hline
\end{tabular}

Tab. č. 2: Výsledky pozorovaní vo vybraných ZŠ počas výučby témy vyučovacej hodiny: Myšlienka-konštrukcia-výroba-využitie

Spracovanie výsledkov výskumu, vyhodnotenie jednotlivých úloh vo všetkých pracovných listoch vybraných skupín žiakov, štatistické spracovanie výsledkov riešení žiakov, výskytu javov v pozorovacích hárkoch a vypracovanie tabuliek, bolo realizované v mesiacoch január až marec 2015 a vypracovanie analýz, komentárov a interpretácí́ bolo plánované na obdobie mesiacov marec až máj 2015. Vyhodnotenie výskumu je rozpracované vo vedeckej monografii (Pavelka- Kozík, a kol. 2015), ktorá prináša celkové súhrnne výsledky výskumu. $Z$ analýz a záverov celkových výsledkov čiastkového výskumu vyplynuli hodnotenia, ktoré umožnili konkrétne formulovat' závery týkajúce sa správnosti vyhotovenia a použitel'nosti navrhnutých metodík a stratégií výučby techniky, učebných pomôcok, listov žiakov a meracích nástrojov priamo v školskej praxi.

\section{Diskusia a závery výskumu}

Ku komparácii, interpretácii a zhrnutiu celkových výsledkov výskumu zameraného na výskyt vybraných klúčových kompetencií žiakov sme pristúpili tak, že sme výsledky spracovali podl'a jednotlivých vybraných kategórií kl’účových kompetencií, k týmto prislúchajúcich vybraných klúčových kompetencií a ich výskytu podla výskumných subkolektívov a podl'a výskytu sledovaných javov v kupinách žiakov. Vzhl'adom na rozmanitost' pozorovaných javov, na spôsob vyhodnocovania pozorovaných javov v závislosti od priameho záznamu výsledku (priamo pozorovaný a zaznamenaný výskyt javu) a nepriameho záznamu (výsledky, ku ktorým pozorovatel' dospel až na základe vyhodnotenia riešení jednotlivých úloh), $\mathrm{k}$ vyhodnoteniu získaných výsledkov uvedených v Tabul'ke 2 a k formulovaniu interpretácii a záverov bolo možné pristúpit' len na základe postupného vyhodnocovania úloh, ktoré obsahovali záznamové hárky z pozorovaní, ale zároveň pracovné listy žiakov. 
Interpretáciu čiastkových výsledkov pre vybranú tému Myšlienka-konštrukcia-výrobavyužitie poskytuje tabul'ka 3

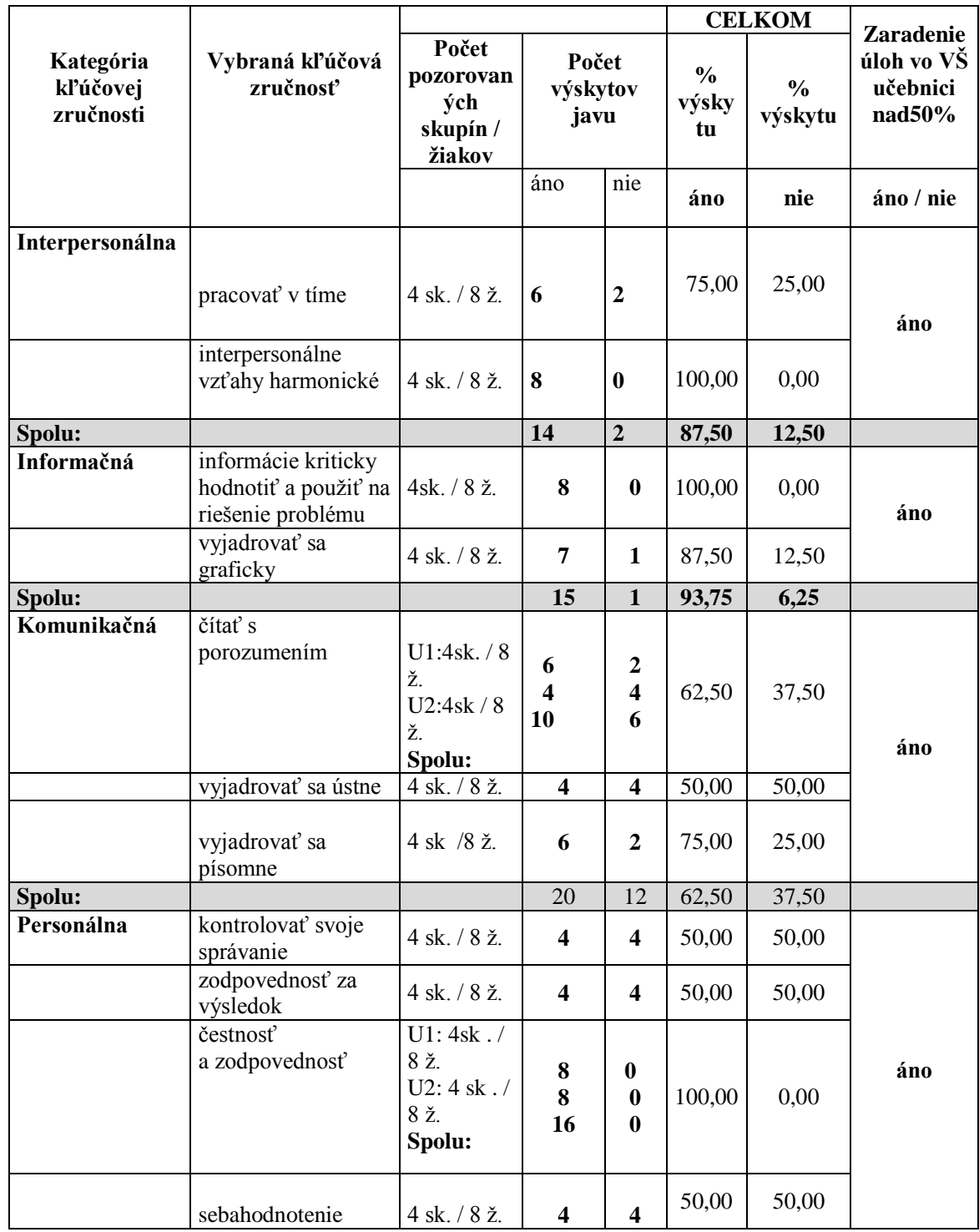




\begin{tabular}{|c|c|c|c|c|c|c|c|}
\hline & & & & & & & \\
\hline Spolu: & & & 28 & 12 & 70,00 & 30,00 & \multirow{3}{*}{ áno } \\
\hline Učebná & $\begin{array}{l}\text { motivovat' seba aj } \\
\text { druhých }\end{array}$ & 4 sk. / 8 ž. & 6 & 2 & 75,00 & 25,00 & \\
\hline & riešit' problém & 4 sk. / 8 ž. & 6 & 2 & 75,00 & 25,00 & \\
\hline Spolu: & & & 12 & 4 & 75,00 & 25,00 & \\
\hline Kognitívna & $\begin{array}{l}\text { kritické myslenie a } \\
\text { hodnotenie }\end{array}$ & $\begin{array}{l}\text { U1: } 4 \text { sk./ } \\
12 \text { ž. } \\
\text { U2: } 4 \text { sk./ } \\
12 \text { ž. } \\
\text { U3: } 4 \text { sk./ } \\
12 \text { ž. } \\
\text { Spolu: }\end{array}$ & $\begin{array}{c}6 \\
5 \\
8 \\
19\end{array}$ & $\begin{array}{l}\mathbf{2} \\
\mathbf{3} \\
\mathbf{0} \\
\mathbf{5}\end{array}$ & 79,16 & 20,84 & áno \\
\hline Spolu: & & & 19 & 5 & 79,16 & 20,84 & \\
\hline
\end{tabular}

Tab. č. 3: Výsledná tabul'ka s interpretáciami výsledkov

Pri vyhodnocovaní výsledkov pozorovania boli pre spracovanie výsledkov použité záznamy v pozorovacom hárku počas vyučovacej hodiny a preberania úloh v $\mathrm{P} 1$ až $\mathrm{P} 4$, teda úlohy, ktoré obsahovali pracovné listy P1 a P4 sú zhrnuté v tabul'ke 2. Nakol'ko orientácia v uvádzanej tabul'ke, vzhl'adom na rozmanitost' údajov, môže byt' nejasná, uvádzame k nej nasledujúce vysvetlivky:

- R (riadok) - riadky R 1 až R 26 sú označené z dôvodu, aby výsledky výskytu jednotlivých javov bolo možné sledovat' pri vyhodnotení úloh (javov), ktoré sa vyskytovali aj opakovane ale v závislosti od použitého pracovného listu P1 až P4,

- Príklad: P1/ZP-5a znamená, že úloha pre žiakov, ktorá mala rozvíjat' vybranú kl'účovú zručnost' a vyvolat' pozorovaný jav sa nachádza v pracovnom liste $\mathrm{P} 1$, zároveň sa nachádza v zošite prezentácie 5 (ZP-5) a úloha bola žiakmi riešená v poradí ako „a“, - „áno“ alebo „nie“ znamená, že pozorovaný jav nastal (,áno“) alebo nenastal („nie“), resp. žiak (alebo skupina žiakov) úlohu riešila úspešne (,áno“) alebo neúspešne (,nie“),

- v poslednom stípci „spolu“ je uvedené „,nad 50 \%“, čo znamená, že žiaci úspešne riešili zadanú úlohu vtedy, ak počet získaných bodov dosiahol nadpolovičnú hranicu z maximálneho počtu bodov, ktoré mohli získat’ ako tím.

Princíp označovania uvedený vo vysvetlivkách je použitý vo formuláciách analýz a interpretácí $\mathrm{k}$ jednotlivým výsledkom realizovaného výskumu.

Súbor vyhotovených predvádzacích zošitov, pracovných listov, metodík a stratégií výučby, konkrétne vyhodnotenie výsledkov práce žiakov na úlohách, ktoré obsahovali pracovné listy, obsahuje spracovaná vysokoškolská učebnica (Ďuriš - Pavelka a kol., 2015).

Na základe čiastkového výskumu, jeho vyhodnotení a vstupných rozhovorov sme dospeli k nasledujúcim záverom: 
- $\quad$ všetci učitelia vyjadrili názor, že vyhotovenie materiálov z hl’adiska obsahu i rozsahu je prijatel'né,

- učitelia žiadali pre žiakov zjednodušit' rozsah realizovaného obsahu,

- učitelia vyjadrili záujem dozvediet' sa, ako model výučby prijmú samotní žiaci, nakol'ko doteraz na hodinách techniky výučba s použitím IT tabule neprebiehala,

- učitelia vyjadrili neistotu, či riešenie úloh žiaci zvládnu a v akej miere sa pracovné listy so žiakmi podarí realizovat'.

Po konečnom vyhodnotení, interpretácií a zhrnutí výsledkov, sme dospeli k nasledujúcim zisteniam na samotný proces výučby hodín techniky a použitel'nost' materiálov pri výučbe vybranej témy vyučovacej hodiny:

- každého z učitel'ov techniky, ktorí vo výučbe uplatnil nami poskytnuté výučbové materiály, metodika výučby vysoko zaujala a prejavil záujem získat' od nás nielen použité, ale i d'alšie výučbové materiály,

- $\quad$ k vlastnej metodike a konštrukcii jednotlivých úloh a činností žiakov učitelia nevyjadrili zásadné pripomienky, tie boli pre učitel’ov i žiakov samotných prijatel'né,

- počet úloh, ktoré obsahovali pracovné listy žiakov, hodnotili učitelia ako vysoký a navrhovali redukovanie počtu úloh a ich zjednodušenie,

- väčšina žiakov počas rozhovorov s učitel’mi vyjadrila názory, že model výučby ich vel'mi zaujal, i napriek tomu, že doteraz takéto úlohy v skupinách a s použitím interaktívnej tabule neriešili,

- žiaci u učitel'ov zist'ovali, kedy najbližšie budú podobným spôsobom opät' vyučovaní,

- použitel’nost' spracovaných materiálov je možná viac menej pri všetkých teoreticko-prakticky orientovaných témach z oblasti predmetu technika.

\section{Záver}

Konkurencieschopnost' a zvýšenie kvality školstva, prináša zmenu prístupu učitel’a a žiaka $\mathrm{k}$ výučbe. Ciel'om je uviest' do praxe systém tvorivo humanistickej výučby. Žiak je aktivitami nútený zmenit' neproduktívne memorovanie za aktívny prístup. Pravidelným tréningom aktivít sa učí tvorivo a kriticky mysliet'. Našou snahou bolo nájst' a vyhodnotit' tie kompetencie, ktoré súviseli s výskumnou prácou nášho kolektívu, naše aktivity boli zamerané na rozvoj klúčových kompetencií žiakov - učebných, komunikačných, informačných, kognitívnych, personálnych a interpersonálnych. Snahou výskumu bolo pripravit', overit' a nahradit' klasické metódy výučby, ktoré sme používali doteraz, novými modernými metódami natol'ko, aby sa získané vedomosti prehĺbili a nadobudnuté zručnosti prepojili s praxou.

Cez naše vynaložené úsilie, žiaci mali problém najmä s tvorivými úlohami, kde bolo treba niečo vyprodukovat', zaostávali $\mathrm{v}$ oblasti kritického myslenia. Aktivity na hodinách $\mathrm{v}$ pilotných školách smerovali $\mathrm{k}$ tomu, aby sa stal vyučovací proces pestrejším a zaujímavejším. Striedajúce sa aktivity vyžadovali pasívny aj aktívny prístup žiaka $\mathrm{k}$ preberanej téme. Snažili sme sa o podrobné rozpracovanie jednotlivých vyučovacích hodín z hladiska metód a foriem, ktoré môžu k stanovenému ciel’u výrazne napomôct'. Práca 
všetkých kolegov na projekte a hlavne ukážky vyučovacích hodín sú výsledkom ich dlhoročnej praxe. Získané vedomosti a zručnosti sa stávajú u žiakov trvalejšími, hodnotnejšími a nie sú odtrhnuté od života.

Nemenej dôležité je prepojenie dosiahnutých znalostí s praxou. Existuje zrejmá súvislost' medzi kl'účovými kompetenciami a celoživotným vzdelávaním a o to v našom školstve ide. Ak učitel'ská verejnost' pochopí, že kl'účové kompetencie a celoživotné vzdelávanie musia tvorit' jeden celok, dosiahneme spoločne výkonný, tvorivý a konkurencie schopný, kvalitný vzdelávací systém.

\section{Literatúra}

Bagalová, L. (2005). Klúčové kompetencie - nové možnosti vo výchove a vzdelávaní. In: Pedagogické spektrum, č. 5-6, 62 -74 s. ISSN 1335-5589.

Belz, H., \& Siegrist, M. (2001). Kličové kompetence a jejich rozvijení: Východiska, metody, cvičeni a hry. Praha: Portál, 376 s. ISBN 80-7178-479-6.

Blaško, M. (2013). Úvod do modernej didaktiky. Dostupné z: http://web.tuke.sk/kip/download/vuc21.pdf.

Čačka, O. (1997). Psychologie vrstev duševního děni osobnosti a jejich autodiagnostika. Brno: MU. ISBN 80-85765-70-5.

Ďuriš, M., J., \& Pavelka, J (Eds.) (2015). Implementácia interaktívnej tabule vo výučbe techniky, fyziky a matematiky v základnej škole. Vydavatel'stvo PU, Grafotlač Prešov, 2015, s. 336, 1. vyd. ISBN 978-80-555-1425-3. EAN 9788055514253.

Ferencová, J., \& Šutáková, V. (2011). Metódy rozvoja učebných kompetencií žiakov (k celoživotnému učeniu sa) v školskej edukácii. In: Didaktika, roč. 2, 149 č. 4, 6-13 s. ISSN 1338-2845

Gavora, Peter \& kol. (2010). Elektronická učebnica pedagogického výskumu. [online].

Bratislava, Univerzita Komenského. Dostupné na: http://www.emetodologia.fedu.uniba.sk/ ISBN 978-80-223-2951-4.

Horká, H. (2000). Výchova pro 21. Století. Koncepce globální výchovy v podmínkach české školy. Brno: Paido. ISBN 80-85931-85-0. (Zdroj: Goleman 1999).

Hrmo, R., \& Turek, I. (2003). Klúčové kompetencie I. 1. vyd., Bratislava: Slovenská technická univerzita. ISBN 80-227-1881-5.

Hyland, T. (1995). Competence, Knowledge and Education. In: Journal of Philosophy of Education. roč. 27, č. 1, s. 57-68.

Kubeš, M., \& Pillerová, D., \& Kurnický, R. (2004). Manažerské kompetence - Způsobilosti výjimečných manažerů. Praha: Grada publishing. ISBN 80-274-0698-9.

Klippert, H. (2013). Nápadnik aktivit pro trénink komunikace a komunikačnich kompetencí. Brno: Edika. ISBN 978-80-266-0126-5.

Ministerstvo školstva slovenskej republiky. (2002). Milénium, národný program výchovy a vzdelávania v slovenskej republike na najbližšich 15 až 20 rokov. Bratislava: IRIS. ISBN 8089018-36-X. 
Kirsti, A-M. (2011). Mapping Digital Competence: Towards a Conceptual Understanding Luxembourg: Publications Office of the European Union European Union

Obdržálek, Z. et al. (2003). Didaktika pre študentov učitel’stva základnej školy. Bratislava: UK. ISBN 80-223-1772-1.

Obdržálek, Z., \& Horváthová, K. et al. (2004). Organizácia a manažment školstva. Terminologický výkladový slovník. Bratislava: SPN. ISBN 80-10-00022-1.

Pavelka, J., \& Kozík, T. (Eds.) (2015). Interaktívne prostredie a klúčové kompetencie. Vedecká monografia. Prešov: PU, ISBN 978-80-555-1424-6

Perrenoud, P. (2000). Construire des compétences dès l'école. In: Pratiques et enjeux pédagogiques. 3. vyd., Paříž: ESF

Petlák, E. (1997). V̌̌eobecná didaktika. Bratislava: Iris. ISBN 80-88778-49-2

Průcha, J., Walterová, E., \& Mareš, J. (2008). Pedagogický slovník. 4. aktualiz. vyd., Praha: Portal. ISBN 978-80-7367-416-8

Průcha, J. (2010). Interkulturni komunikace. Praha: Grada. ISBN 978-80-247-3069-1.

Romainville, M. (1996). L'irrésistible ascension du terme compétence en éducation. In: Enjeux. 37/38, vydanie marec/jún 1996

Sundberg, N. D. et al. (1978). Towards assessments of personal competence and incompetence in life situations. In: Annual Review of Psychology. vyd. 29, s. 179 - 221.

Švec, V. (1998). Kličové dovednosti ve vyučováni a vycviku. Brno: Masarykova univerzita. ISBN 80-210-1937-9. s.181).

Turek, I. (2002). Kl'účové kompetencie žiakov. In: Pedagogické rozhl’ady. č. 2, s. 3-7. ISSN 1335-0404.

Turek, I. (2003). Klúčové kompetencie. Bratislava: Metodicko-pedagogické centrum. 40 s. ISBN 80-8052-174-3.

Turek, I. (2008). Didaktika. Bratislava: Iura Edition, s. 53. ISBN 978-80-8078-198-9

Veteška, J., \& Tureckiová, M. (2008). Kompetence ve vzdělání. Praha: Grada. ISBN 978-80247-1770-8.

Walterová, E. et al. (2004). Úloha školy v rozvoji vzdělanosti. 1. a 2. diel. Brno: Paido. ISBN 80-7315-083-2.

Statpedu (2016). Kompetencie. Dostupné http://www.statpedu.sk/Projekty/PISA/Pisa_mat_gram_sprava.pdfjjhgh 